\title{
Fenton Process Optimization with Landfill Leachate in Janczyce as an Example
}

\author{
Joanna Muszyńska, Lukasz Bąk, Jarosław Górski , Katarzyna Górska, \\ Aleksandra Sałata, Jarosław Gawdzik*
}

Kielce University of Technology, Faculty of Environmental, Geomatic and Energy Engineering, al. Tysiąclecia Państwa Polskiego 7, 25-314 Kielce, Poland

Received: 3 June 2020

Accepted: 26 November 2020

\begin{abstract}
One of the advanced oxidation methods is the Fenton's reaction which uses a mixture of iron(II) and hydrogen peroxide to generate hydroxyl radicals. The Fenton process efficiency is influenced by a number of factors including the $\mathrm{pH}$, the $\mathrm{Fe}^{2+}: \mathrm{H}_{2} \mathrm{O}_{2}$ relation or the $\mathrm{Fe}^{2+}$ dose. The aim of the study was to optimize the Fenton method in the application for landfill leachate treatment, with the landfill in Janczyce (Świętokrzyskie Voivodeship) as an example. The sequence of determining the most advantageous conditions for the use of Fenton's reagent was as follows: A - the $\mathrm{pH}$ effect; $\mathrm{B}$ - the oxidation time effect; $\mathrm{C}-$ the $\mathrm{Fe}^{2+}: \mathrm{H}_{2} \mathrm{O}_{2}$ relation effect; $\mathrm{D}$ - the $\mathrm{Fe}^{2+}$ dose effect. The optimum catalyst/oxidant ratio of 0.125 was determined. The optimum process time of 90 minutes was determined. It was demonstrated that the Fenton process can be effectively carried out already at the $\mathrm{pH}$ of 4 . A reduction by $75 \%$ for the TOC and by $89 \%$ for the COD, respectively, was obtained.
\end{abstract}

Keywords: landfill leachate, Fenton's reaction, wastewater treatment, carbon contaminants removal

\section{Introduction}

The operation of a landfill and the physical, chemical and biological transformations occurring within it result in the emergence of numerous environmental hazards due to, inter alia, emissions of landfill gases, microorganisms or leachates [1]. Leachate is infiltration waters flowing through the landfill cap along with both the waste components washed out and dissolved in them and the products of biochemical reactions occurring in the waste bed [2-5]. The resulting highly concentrated leachate waters require specialized treatment. When

*e-mail: jgawdzik@tu.kielce.pl selecting a leachate treatment technology, minimum costs of leachate treatment need to be maintained, and e.g. the changing chemical composition and the volume of leachate need to be taken into account. It is also of significance to make maximum use of the existing landfill potential e.g. the existing heat or energy sources [6-8]. Conventional waste treatment or pre-treatment methods are sometimes insufficiently effective. Therefore, advanced oxidation processes (AOP) such as photo-Fenton $\left(\mathrm{UV} / \mathrm{H}_{2} \mathrm{O}_{2}+\mathrm{Fe}^{2+}\right)$, electroFenton, ozone $\left(\mathrm{O}_{3}\right)$ oxidation, oxidation $\mathrm{O}_{3}+\mathrm{UV}$, $\mathrm{O}_{3}+\mathrm{UV}+\mathrm{H}_{2} \mathrm{O}_{2}$, percarbonate oxidation or the Fenton process $\left(\mathrm{H}_{2} \mathrm{O}_{2}+\mathrm{Fe}^{2+}\right)$ are increasingly applied. In view of, inter alia, the wide range of application, the high non-selectivity of the $\mathrm{OH}$, and the simplicity of running the process, the Fenton process is the most popular 
of the AOP methods, and its main disadvantage is the generation of sediments which need to be properly managed [2, 5, 6, 9-12].

In general, the Fenton process involves a reaction of $\mathrm{Fe}^{2+}$ ions with hydrogen peroxide that forms hydroxyl radicals (at the $\mathrm{pH}$ value below 5) (Eq. 1). Equation (1) is regarded as the basis of the Fenton's reaction $[9,10]$; however, in order to understand the entire mechanism, other reactions should be taken into account. The high oxidation/reduction potential of the formed $\mathrm{OH}$ hydroxyl radicals (the oxidative potential of $2.76 \div 2.80 \mathrm{~V}$ ) enables the oxidation of most contaminants to simpler biodegradable forms. In addition to hydroxyl radicals $\left({ }^{\circ} \mathrm{OH}\right)$, the whole series of reactions in the Fenton process also produces hydroperoxyl radicals $\left({ }^{\circ} \mathrm{O}_{2} \mathrm{H}\right)$ which are also able to eliminate contaminants yet much slower than the ${ }^{\circ} \mathrm{OH}$ radicals [2, 6, 12-15].

$$
\begin{gathered}
\mathrm{H}_{2} \mathrm{O}_{2}+\mathrm{Fe}^{2+} \rightarrow \mathrm{Fe}^{3+}+\cdot \mathrm{OH}+\mathrm{OH}^{-} \\
\mathrm{k}_{1}=40 \div 80 \mathrm{~L} \mathrm{~mole}^{-1} \mathrm{~s}^{-1}
\end{gathered}
$$

The efficiency of contaminant elimination due to the application of Fenton's reaction is determined by a number of parameters including the $\mathrm{pH}$ value, $\mathrm{H}_{2} \mathrm{O}_{2}$ and $\mathrm{Fe}^{2+}$ doses, the $\mathrm{Fe}^{2+}$ to $\mathrm{H}_{2} \mathrm{O}_{2}$ ratio, and the process temperature and duration.

For the Fenton process, the optimum $\mathrm{pH}$ range at which the best treatment effects can be obtained is $2 \div 5$. Higher $\mathrm{pH}$ values contribute to a decrease in reaction efficiency due to the formation of insoluble $\mathrm{Fe}(\mathrm{OH})_{3}$. On the other hand, at a very low $\mathrm{pH}$ value, the $\left[\mathrm{Fe}\left(\mathrm{H}_{2} \mathrm{O}\right)_{6}\right]^{2+}$ complexes are formed, which react with $\mathrm{H}_{2} \mathrm{O}_{2}$ more slowly than the others. In addition, hydrogen peroxide in the presence of a high $\mathrm{H}^{+}$ion concentration forms a stable $\left[\mathrm{H}_{3} \mathrm{O}_{2}\right]^{+}$ion; hydrogen peroxide is less stable and decreases reactivity with iron ions $[10,16]$. A study by Zhang et al. [16] demonstrated that for landfill leachate, the best effect in COD and TOC values decrease was obtained at the $\mathrm{pH}$ of $2 \div 3$.

Hydrogen peroxide and iron(II) ions are the main chemical reagents used in the conventional Fenton's reaction, therefore their doses and mutual relation are significant parameters affecting the process efficiency. An increase in the $\mathrm{H}_{2} \mathrm{O}_{2}$ dose results in better effects of the contaminant oxidation process, but too high a dose of $\mathrm{H}_{2} \mathrm{O}_{2}$ in relation to the substrate may cause the $\mathrm{OH}$ radical binding by $\mathrm{H}_{2} \mathrm{O}_{2}$. Hydrogen peroxide is harmful to many organisms, which is of significance if the Fenton process is carried out prior to biological treatment $[12,17,18]$. The unused portion of hydrogen peroxide results in an overvaluation of the COD being determined (in a reaction with strong oxidants e.g. potassium dichromate used to determine the COD, hydrogen peroxide acts as a reducing agent). In such a case, it is necessary to check on the residual $\mathrm{H}_{2} \mathrm{O}_{2}$ content in the treated wastewater. Where the residual $\mathrm{H}_{2} \mathrm{O}_{2}$ content is found, the COD value needs to be corrected using the following formula [19]:

$$
\mathrm{COD}=\mathrm{COD}_{\mathrm{M}}-\mathrm{d} \cdot \mathrm{f} \mathrm{mg} / \mathrm{L}
$$

$\mathrm{COD}_{\mathrm{M}}-\mathrm{COD}$ value obtained from titration, $\mathrm{mg} / \mathrm{L}$

$\mathrm{d}$ - residual $\mathrm{H}_{2} \mathrm{O}_{2}$ concentration in the sample, $\mathrm{mg} / \mathrm{L}$

$\mathrm{f}$ - correction factor of 0.25 (for the range of $20 \div 1000 \mathrm{mg} \mathrm{H}_{2} \mathrm{O}_{2} / \mathrm{L}$ ).

Therefore, it is each time necessary to conduct testing on a laboratory scale to determine the optimum doses and $\mathrm{H}_{2} \mathrm{O}_{2} / \mathrm{Fe}^{2+}$ relations [10]. A high molar ratio above the stoichiometric reduction may be associated with the formation of a number of side reactions which affect the Fenton's reaction efficiency [16].

It is recommended that the process temperature should fall within the range of $20 \div 40^{\circ} \mathrm{C}[10,19,20]$.

According to a study conducted by E. R. B. Dantas et al. [21], the optimum conditions for running the Fenton process for the treatment of landfill leachates are: an $\mathrm{Fe}^{2+}$ dose of $12 \mathrm{~g} / \mathrm{L}$, a $\mathrm{H}_{2} \mathrm{O}_{2} / \mathrm{Fe}^{2+}$ molar ratio of 9, the $\mathrm{pH}$ of 2.0, oxidation duration of $30 \mathrm{~min}$, flocculation duration of $10 \mathrm{~min}$, and sedimentation duration of 15 min. At such parameters, the following values were decreased: COD by approx. 87\%, BOD by approx. 70\%, and the TC (residual true colour) by over $90 \%$, at initial values of the COD of $17988 \mathrm{mg} / \mathrm{L}, \mathrm{BOD}$ of $6012 \mathrm{mg} / \mathrm{L}$, and TC of $4900 \mathrm{uH}$. As regards the study conducted by S.T. Gowd and S. Yashaswini [22], the optimum parameters of running the Fenton process was the reaction duration of $60 \mathrm{~min}$, the $\mathrm{pH}$ of 3.0, $\mathrm{a} \mathrm{H}_{2} \mathrm{O}_{2}$ dose of $0.5 \mathrm{M}$ and a $\mathrm{Fe}^{2+}$ dose of $1000 \mathrm{mg} / \mathrm{L}$. At the following initial wastewater parameters: BOD of $2400 \mathrm{mg} / \mathrm{L}$, COD of $13500 \mathrm{mg} / \mathrm{L}$ and chlorides of $3000 \mathrm{mg} / \mathrm{L}$, a reduction in the parameter values by $48 \%$ (BOD), $67 \%$ (COD) and 40\% (chlorides) was obtained. On the other hand, H. Zhang et al. [16] obtained the optimum process values at the oxidation time of $30 \mathrm{~min}$, the $\mathrm{pH}$ of 2.5 , the molar ratio of $\mathrm{H}_{2} \mathrm{O}_{2}$ do $\mathrm{Fe}$ (II) of 1.5 , at the following parameter initial values in landfill leachate: the $\mathrm{pH}$ of $6.65 \div 6.69$, COD of $8298 \div 8894 \mathrm{mg} / \mathrm{L}$, TOC of $2040 \div 2207 \mathrm{mg} / \mathrm{L}$, and the alkalinity as $\mathrm{CaCO}_{3}$ of $3500 \div 4600 \mathrm{mg} / \mathrm{L}$.

The above results clearly show that it is each time necessary to conduct testing on a laboratory scale to determine the optimum doses of $\mathrm{H}_{2} \mathrm{O}_{2}$ and $\mathrm{Fe}^{2+}$, the $\mathrm{H}_{2} \mathrm{O}_{2} / \mathrm{Fe}^{2+}$ relations, the $\mathrm{pH}$ and the process duration.

\section{Experimental}

The leachate samples were collected and stored, and their chemical composition was studied in accordance with the existing standards PN-ISO 5667-10:1997. Leachate samples were collected from a landfill with an area of 3.64 ha in Janczyce (Świętokrzyskie voivodeship), which is a part of the Municipal Waste Disposal Plant in Janczyce. The Waste Disposal Plant in Janczyce has been operating since 2003, and provides services to approx. 150000 inhabitants. On the landfill, waste after mechanical processing of mixed municipal waste, sorting remnants and other non-recyclable waste 
are deposited. According to estimates, over 44 thousand $\mathrm{Mg}$ of waste are neutralized on the landfill on an annual basis, and the operation of the landfill generated from approx. $3600 \mathrm{~m}^{3}$ of leachate per year (2012) to over $10000 \mathrm{~m}^{3}$ leachate per year (2015).

Laboratory tests for the landfill leachate pretreatment were carried out on leachate samples with a volume of $0.6 \mathrm{~L}$ (the sample volume was selected in such a way that all the parameters being determined could be analysed). In the tests, the following analytical grade reagents were used: $\mathrm{FeSO}_{4} 7 \mathrm{H}_{2} \mathrm{O}$ (used as a $5 \%$ solution and converted into a $\mathrm{Fe}^{2+}$ dose), $30 \% \mathrm{H}_{2} \mathrm{O}_{2}, \mathrm{H}_{2} \mathrm{SO}_{4}$ (concentration of $98 \%$ ), $\mathrm{KOH}$ (a $10 \%$ solution). The sequence of determining the most advantageous conditions for the use of Fenton's reagent was as follows:

- A - the $\mathrm{pH}$ effect was analyzed for the $\mathrm{pH}$ of $2.0 \div 5.0$ (an interval of 1.0); duration of $120 \mathrm{~min}$; weight relations between $\mathrm{Fe}^{2+}$ and $\mathrm{H}_{2} \mathrm{O}_{2}$ of $1: 3$ and 1:8; $\mathrm{a} \mathrm{Fe}^{2+}$ dose of $1000 \mathrm{mg} / \mathrm{L}$ and $1500 \mathrm{mg} / \mathrm{L}$;

- B - the oxidation time effect was analysed for the duration of $10 \mathrm{~min}, 30 \mathrm{~min}, 60 \mathrm{~min}, 90 \mathrm{~min}$, $120 \mathrm{~min}, 150 \mathrm{~min}, 180 \mathrm{~min}, 210 \mathrm{~min}$; weight relations between $\mathrm{Fe}^{2+}$ and $\mathrm{H}_{2} \mathrm{O}_{2}$ of 1:3 and 1:8; a Fe ${ }^{2+}$ dose of $1000 \mathrm{mg} / \mathrm{L}$ and $1500 \mathrm{mg} / \mathrm{L}$;

- $\mathrm{C}$ - the $\mathrm{Fe}^{2+}: \mathrm{H}_{2} \mathrm{O}_{2}$ relation effect was analysed for the weight relations between $\mathrm{Fe}^{2+}$ and $\mathrm{H}_{2} \mathrm{O}_{2}$ of $1: 2$, 1:3, 1:4, 1:5, 1:6, 1:7, 1:8, 1:9, 1:10; a $\mathrm{Fe}^{2+}$ dose of $100 \mathrm{mg} / \mathrm{L}, 500 \mathrm{mg} / \mathrm{L}, 1000 \mathrm{mg} / \mathrm{L}$ and $1500 \mathrm{mg} / \mathrm{L}$; oxidation time of $90 \mathrm{~min}$; the initial $\mathrm{pH}$ of 4.0;

- $\mathrm{D}$ - the $\mathrm{Fe}^{2+}$ dose effect was analysed for a $\mathrm{Fe}^{2+}$ dose ranging from 1000 to $1800 \mathrm{mg} / \mathrm{L}$ (an interval every $50 \mathrm{mg} / \mathrm{L}$ ); $\mathrm{pH}$ of 4.0; duration of $90 \mathrm{~min}$; a weight relation between $\mathrm{Fe}^{2+}$ and $\mathrm{H}_{2} \mathrm{O}_{2}$ of $1: 8$;

The tests were carried out at $20^{\circ} \mathrm{C} \pm 1^{\circ} \mathrm{C}$, the $\mathrm{pH}$ was corrected using concentrated $\mathrm{H}_{2} \mathrm{SO}_{4}$ and a $10 \% \mathrm{KOH}$ solution. Following the $\mathrm{pH}$ correction, a $\mathrm{Fe}^{2+}$ dose was added at once to $\mathrm{H}_{2} \mathrm{O}_{2}$ to the leachate sample, and after the pre-defined oxidation time (the mixing rate during the reaction of 50 revolutions/min) in a Conbest JLT6 flocculator, the samples were neutralised with $10 \%$ $\mathrm{KOH}$ to the $\mathrm{pH}$ of approx. 7.5. Then, the leachate was mixed for $30 \mathrm{~min}$ at a rate of 10 revolutions $/ \mathrm{min}$, and afterwards sedimented for $30 \mathrm{~min}$. After this stage, the effect of particular process elements on the efficiency of contaminant removal from landfill leachate was analyzed.

Both prior to and following the treatment process, the contents of the following were determined: COD, TOC, selected elements including heavy metals (Al, $\mathrm{Ca}, \mathrm{Cd}, \mathrm{Cu}, \mathrm{Cr}, \mathrm{Fe}, \mathrm{Mg}, \mathrm{Na}, \mathrm{Ni}, \mathrm{K}, \mathrm{Pb}, \mathrm{Zn}$ ), and their $\mathrm{pH}$, specific conductance, total amount of dissolved substances, salinity, temperature and the redox potential were measured. All analyses were conducted in line with the existing standards:

- chemical oxygen demand was determined by the Spectroquant photometric method - determination by cuvette tests using a MERCK Spectroquant Nova 60 spectrophotometer after pre-heating in a MERCK TR 320 thermoreactor $\left(120 \mathrm{~min}\right.$ at $\left.148^{\circ} \mathrm{C}\right)$; depending on the method, the limit of quantification was $10 \div 10000 \mathrm{mg} / \mathrm{L}$, a method analogous to PN-ISO 15705:2005;

- total organic carbon was determined by the UV oxidation with peroxydisulphate method using a StarTOC System apparatus according to PN-EN 1484:1999; depending on the method, the limit of quantification was $0.050 \div 1000 \mathrm{mg} / \mathrm{L}$;

- the $\mathrm{pH}$ was determined by the potentiometric method using a $\mathrm{pH}$ meter according to PN-EN ISO 10523:2012;

- total dissolved solids, temperature and specific conductance were determined using a Mettler Toledo SevenMulti $\mathrm{pH}$ meter/conductometer;

- Al, Ca, Cd, Cu, Cr, Fe, Mg, Na, Ni, K, Pb and $\mathrm{Zn}$ were determined using a Parkin Elmer ICP inductively coupled plasma optical emission spectrometer according to PN-EN ISO 11885:2009 after previous aqua regia digestion according to PN-EN ISO 15587-1:2005; the limit of quantification ranged from 0.00001 to $0.0001 \mathrm{mg} / \mathrm{L}$.

\section{Results and Discussion}

The study results obtained following the analysis of leachate are presented in Figs 1-6 and in Table 1. Raw leachate COD was $(2789 \pm 12) \mathrm{mg} \mathrm{O}_{2} / \mathrm{L}$, the TOC was $(789 \pm 1) \mathrm{mg} \mathrm{C} / \mathrm{L}$, while the $\mathrm{pH}$ was 6.794 . Initially, the $\mathrm{pH}$ effect on the efficiency of landfill leachate remediation using the Fenton's reagent at the $\mathrm{Fe}(\mathrm{II}) /$ $\mathrm{H}_{2} \mathrm{O}_{2}$ relation was of 0.125 and 0.333 , respectively. The tests were carried out at the $\mathrm{pH}$ ranging from 2 to 5 , in increments of 1 . The effects of COD decrease for doses of $\mathrm{Fe}(\mathrm{II})$ of, respectively, $1000 \mathrm{mg} / \mathrm{L}$ and $1500 \mathrm{mg} / \mathrm{L}$ are presented in Fig. 1. The process duration was arbitrarily adopted to be $120 \mathrm{~min}$. The highest COD values after time $\mathrm{t}$ was obtained for the test carried out at the $\mathrm{pH}$ of 2 (Fig. 1). Here, the effect of $\mathrm{H}_{3} \mathrm{O}^{+}$ cation excess on the effect of $\mathrm{HO}^{\circ}$ radical scavenging is clearly noticeable. For a higher $\mathrm{H}_{3} \mathrm{O}^{+}$oxonium ion concentration, these ions can successfully compete with organic matter for precedence in the reaction with hydroxyl radicals:

$$
\mathrm{H}_{3} \mathrm{O}^{+}+\mathrm{HO}^{\cdot}+\mathrm{e}^{-} \rightarrow 2 \mathrm{H}_{2} \mathrm{O}
$$

Increasing the $\mathrm{pH}$ by 1 to a value of 3 has a marked effect on the COD of treated leachate. However, similar or even better results may be obtained when the reaction is carried out at the $\mathrm{pH}$ of 4 . Since the $\mathrm{pH}$ of raw leachate is 6.794 , a decrease in the $\mathrm{pH}$ to 3 with $\mathrm{H}_{2} \mathrm{SO}_{4}$ appears to be disputable. On the other hand, too low a portion of acid at which the $\mathrm{pH}$ of 5 was obtained will not be optimum (Fig. 1). In this case, theoretical premises indicate the decreasing probability of the formation of the required number of $\mathrm{HO}^{*}$ radicals. In view of the above, the subsequent tests were conducted at the $\mathrm{pH}$ of 4 . 


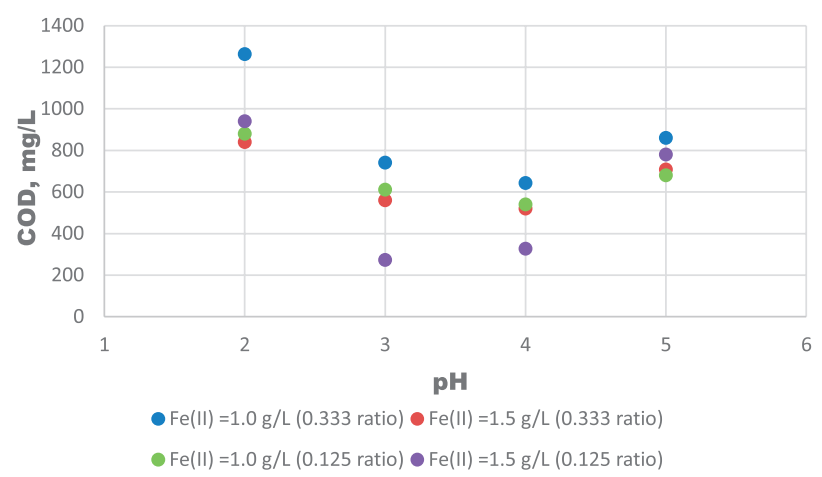

Fig. 1. Effect of the solution $\mathrm{pH}$ on the COD of the treated effluent.

After the $\mathrm{pH}$ value determination, the effect of process duration on the efficiency of landfill leachate decontamination was measured. Relations and doses similar to those at the first stage were adopted; however, the oxidation reaction was carried out within a time interval from 10 to $210 \mathrm{~min}$. The test results are presented below in Fig. 2.

The tests into the effects of the duration of landfill leachate decontamination were carried out at the adopted catalyst dose of 1000 and $1500 \mathrm{mg} / \mathrm{L}$, the catalyst/oxidant relation of 0.125 and 0.333 , and at the reference pH. It was demonstrated (Fig. 2) that for the selected catalyst dose combinations, the required reaction time should not be shorter than 90 minutes. The application of shorter time does not ensure the required decontamination efficiency measured by the COD loss (Fig. 2). Extending the reaction time to 120 minutes does not significantly changes the process efficiency.

The application of longer durations appears to be pointless, and may contribute to the worsening of remediation effects, particularly in economic terms. In the third step, the effect of the $\mathrm{Fe}(\mathrm{II}) / \mathrm{H}_{2} \mathrm{O}_{2}$ relation on the COD and TOC of treated leachate (retentates). The study was carried out at nine different catalyst/oxidant relations ranging from 0.1 to 0.5 , and the test results are presented in Figs 3 and 4 in order to select the optimum value. The test was carried out for catalyst doses of 500,

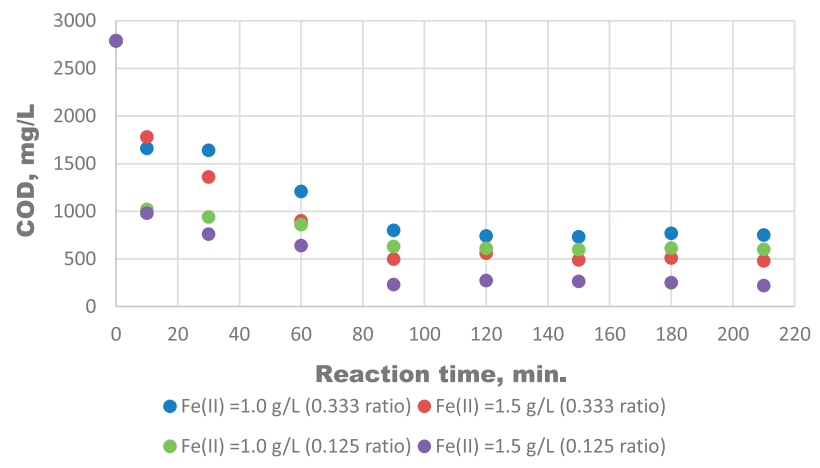

Fig. 2. The effect of the oxidation process duration on the COD of treated leachate.



Fig. 3. The effect of $\mathrm{Fe}^{2+} / \mathrm{H}_{2} \mathrm{O}_{2}$ weight ratio value on the treated leachate COD.

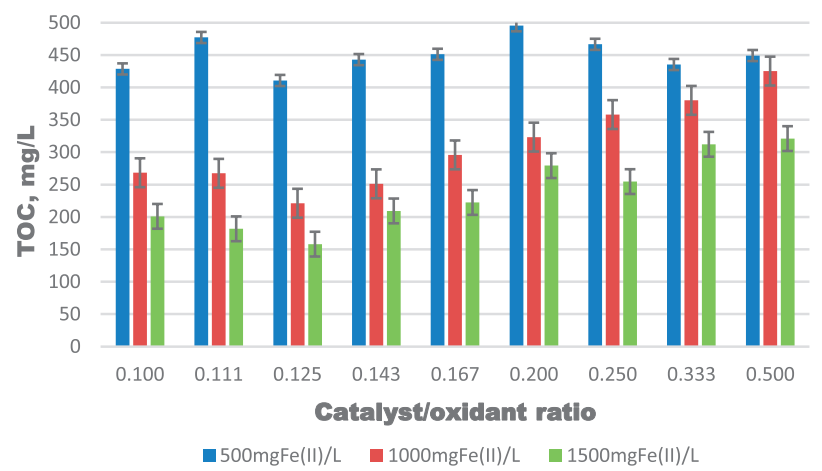

Fig. 4. The effect of $\mathrm{Fe}^{2+} / \mathrm{H}_{2} \mathrm{O}_{2}$ weight ratio value on the treated leachate TOC.

1000 and $1500 \mathrm{mg} \mathrm{Fe}(\mathrm{II}) / \mathrm{L}$ at the optimum process duration and $\mathrm{pH}$. Based on the results obtained at this stage of the study, it can be concluded that maintaining the catalyst/oxidant relation ranging from 0.111 to 0.125 yields the best results for the adopted $\mathrm{Fe}^{2+}$ catalyst doses in terms of the leachate COD and TOC elimination (Figs 3 and 4).

The greatest increase in efficiency was noted when the $\mathrm{Fe}^{2+} / \mathrm{H}_{2} \mathrm{O}$, ratio was increased from 0.100 to 0.111 . This is due to the fact that in order to obtain high efficiency of the Fenton process, an appropriately high concentration of $\mathrm{Fe}^{2+}$ ions is required. As demonstrated by Barbusiński in the studies [10, 15], too high a concentration of $\mathrm{Fe}^{2+}$ ions in relation to $\mathrm{H}_{2} \mathrm{O}_{2}$ may, however, decrease the hydroxyl radical concentration in the reaction as below:

$$
\mathrm{Fe}^{2+}+\mathrm{HO}^{\cdot} \rightarrow \mathrm{Fe}^{3+}+\mathrm{OH}^{-}
$$

This effect becomes noticeable when the value of 0.125 is exceeded, particularly for the relation of 0.200 . On the other hand, at a too low catalyst/oxidant quotient (e.g. 0.100), the iron(II) dose may be insufficient to form the required number of hydroxyl radicals, as presented using the general Fenton's reaction equation (1). It is worth mentioning that the optimum $\mathrm{HO}^{*}$ radical 


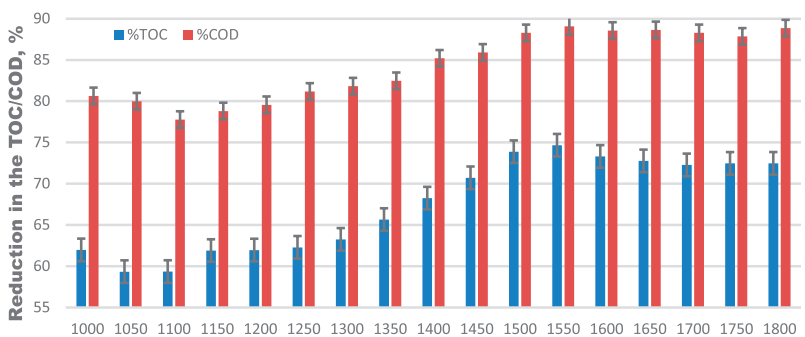

Dose of Fe(II), mg/L

Fig. 5. Percentage reduction in the TOC and COD $(\alpha=0.05$; $\mathrm{df}=33)$.

concentration is the main factor affecting the efficiency of the landfill leachate decontamination process. Given that the best results in the TOC elimination were obtained at the weight ratio of 0.125 , this particular relation was adopted for the subsequent stages of the study (Fig. 4).

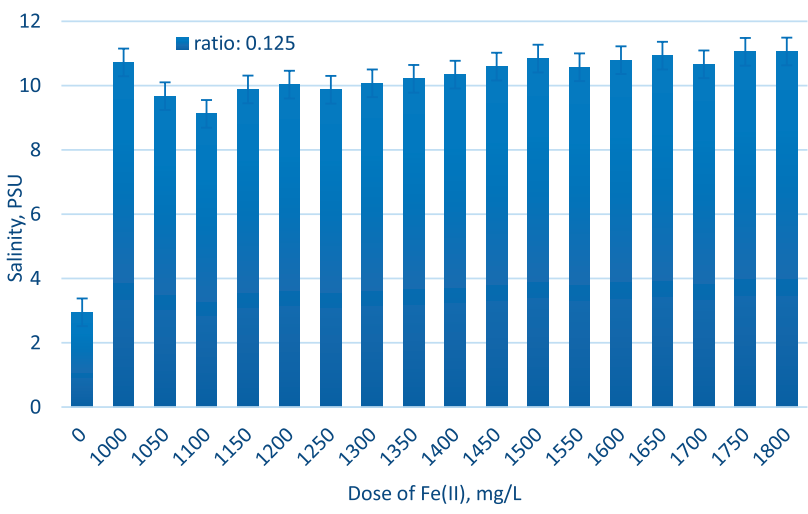

Fig. 6. Dependence of the solution salinity on the Fe(II) dose function $(\alpha=0.05 ; \mathrm{df}=16)$.

Then, the susceptibility of landfill leachate to oxidation by the Fenton's method using hydrogen peroxide at the set $\mathrm{pH}$ of 4.0 , the catalyst/oxidant

Table 1 . Heavy metal content (mg/L) of leachate samples before and after the Fenton process.

\begin{tabular}{|c|c|c|c|c|c|c|c|c|}
\hline Sample & $\mathrm{HMs}$ & $\mathrm{Cd}$ & $\mathrm{Cu}$ & $\mathrm{Cr}$ & $\mathrm{Ni}$ & $\mathrm{Pb}$ & $\mathrm{Fe}$ & $\mathrm{Zn}$ \\
\hline \multirow{4}{*}{ Raw } & Mean & 0.000 & 0.139 & 0.094 & 0.067 & 0.011 & 24.49 & 0.767 \\
\hline & Min & 0.000 & 0.102 & 0.089 & 0.066 & 0.006 & 24.11 & 0.691 \\
\hline & Max & 0.002 & 0.144 & 0.099 & 0.068 & 0.015 & 24.53 & 0.771 \\
\hline & Median & 0.000 & 0.138 & 0.094 & 0.066 & 0.009 & 24.51 & 0.766 \\
\hline \multirow{4}{*}{1000} & Mean & 0.000 & 0.000 & 0.020 & 0.069 & 0.001 & 0.356 & 0.723 \\
\hline & Min & 0.000 & 0.000 & 0.016 & 0.049 & 0.000 & 0.351 & 0.693 \\
\hline & Max & 0.000 & 0.000 & 0.027 & 0.081 & 0.007 & 0.357 & 0.762 \\
\hline & Median & 0.000 & 0.000 & 0.020 & 0.071 & 0.000 & 0.355 & 0.720 \\
\hline \multirow{4}{*}{1150} & Mean & 0.000 & 0.039 & 0.068 & 0.126 & 0.002 & 8.129 & 0.735 \\
\hline & Min & 0.000 & 0.033 & 0.030 & 0.071 & 0.000 & 8.111 & 0.706 \\
\hline & Max & 0.000 & 0.052 & 0.102 & 0.161 & 0.007 & 8.133 & 0.762 \\
\hline & Median & 0.000 & 0.037 & 0.066 & 0.129 & 0.001 & 8.131 & 0.737 \\
\hline \multirow{4}{*}{1300} & Mean & 0.002 & 0.203 & 0.040 & 0.055 & 0.060 & 12.23 & 0.871 \\
\hline & Min & 0.001 & 0.069 & 0.025 & 0.043 & 0.051 & 12.12 & 0.870 \\
\hline & Max & 0.003 & 0.369 & 0.072 & 0.063 & 0.064 & 12.30 & 0.873 \\
\hline & Median & 0.002 & 0.185 & 0.034 & 0.059 & 0.060 & 12.23 & 0.872 \\
\hline \multirow{4}{*}{1550} & Mean & 0.002 & 0.018 & 0.030 & 0.038 & 0.035 & 15.26 & 0.381 \\
\hline & Min & 0.000 & 0.000 & 0.019 & 0.035 & 0.009 & 15.17 & 0.379 \\
\hline & Max & 0.004 & 0.072 & 0.038 & 0.041 & 0.048 & 15.31 & 0.383 \\
\hline & Median & 0.000 & 0.000 & 0.029 & 0.039 & 0.038 & 15.26 & 0.381 \\
\hline \multirow{4}{*}{$\begin{array}{c}1800 \\
\mathrm{mgFe} / \mathrm{L}\end{array}$} & Mean & 0.001 & 0.199 & 0.064 & 0.056 & 0.064 & 7.982 & 0.231 \\
\hline & Min & 0.000 & 0.180 & 0.023 & 0.036 & 0.058 & 7.911 & 0.229 \\
\hline & Max & 0.002 & 0.250 & 0.246 & 0.091 & 0.070 & 8.002 & 0.232 \\
\hline & Median & 0.001 & 0.191 & 0.030 & 0.041 & 0.064 & 7.980 & 0.231 \\
\hline
\end{tabular}


relation of 0.125 , and for the duration of 90 minutes was checked. The effects of the treated leachate COD and TOC values decrease for the catalyst doses ranging from 1000 to $1800 \mathrm{mg} / \mathrm{L}$ were noted, and the test results are presented in Fig. 5. With an increase in iron(II) dose within the range from 1000 to $1250 \mathrm{mg} \mathrm{Fe}(\mathrm{II}) / \mathrm{L}$, no improvement in the effects of the COD and TOC value decrease was noted. Only after exceeding the value of $1300 \mathrm{mg} \mathrm{Fe}(\mathrm{II}) / \mathrm{L}$, an improvement in the effects of remediation, measured particularly by the TOC indicator, was noted. The greatest changes were observed for doses ranging from 1350 to $1500 \mathrm{mg} / \mathrm{L}$. On the other hand, a high rate of changes in the efficiency of the COD and TOC removal was noted for doses ranging from 1450 to $1500 \mathrm{mg}$ $\mathrm{Fe}(\mathrm{II}) / \mathrm{L}$. For this reason, the optimum catalyst dose of $1550 \mathrm{mg} / \mathrm{L}$ was selected (Fig. 5). At the adopted catalyst/oxidant relation of 0.125 , the complementary oxidant dose is $12400 \mathrm{mg} \mathrm{H}_{2} \mathrm{O}_{2} / \mathrm{L}$.

For the optimum conditions Fenton process conditions, the TOC value of $(199 \pm 1) \mathrm{mg} \mathrm{C} / \mathrm{L}$ and the $\mathrm{COD}$ value of $(305 \pm 5) \mathrm{mg} \mathrm{O} / \mathrm{L}$ were obtained in the treated leachate. A $75 \%$ level of the landfill leachate TOC elimination and the COD elimination by over $89 \%$ were obtained. The disadvantage of the system is a significant increase in salinity, which is illustrated in Figure 6. What is interesting, for the adopted catalyst doses the effect of the catalyst dose on the treated wastewater salinity level did not become noticeable. On the other hand, a properly run Fenton process may contribute to a slight decrease in heavy metal concentrations (Table 1). In view of the above, it appears that the Fenton's method is a promising technique of organic contaminant elimination from landfill leachate, and may be an effective supplement and/or support for other techniques, including the membrane methods.

\section{Conclusions}

The conducted study demonstrated that this method for the formation of hydroxyl radicals enabled an effective decrease in the organic contaminant content of landfill leachate measured by the summary indicators as the TOC or COD. The Fenton process was run at the $\mathrm{Fe}(\mathrm{II})$ catalyst $/ \mathrm{H}_{2} \mathrm{O}_{2}$ oxidant weight ratio ranging from 0.100 to 0.500 at the $\mathrm{Fe}(\mathrm{II})$ dose ranging from 1000 to $1800 \mathrm{mg} / \mathrm{L}$, in an increment of $50 \mathrm{mg} / \mathrm{L}$ within the $\mathrm{pH}$ ranging from 2 to 5 . In raw and treated leachate, the COD, TOC, salinity and selected heavy metal contents were determined. It was demonstrated that with an increase in the $\mathrm{Fe}$ (II) dose, an improvement occurs in the efficiency of landfill leachate remediation, measured by the loss of the TOC and COD - however, only to a limited extent and to a certain degree. Moreover, a clear increase in the retentate salinity was indicated. The optimum catalyst/oxidant ratio of 0.125 was determined. The optimum process time of 90 minutes was determined. It was demonstrated that the Fenton process can be effectively carried out already at the $\mathrm{pH}$ of 4 . A reduction by $75 \%$ for the TOC and by $89 \%$ for the COD, respectively, was obtained. This confirmed the Fenton's method efficiency in the application for the landfill leachate pre-treatment.

\section{Acknowledgements}

The project was supported by the program of Minister of Science and Higher Education under the name' Regional Initiative of Excellence in 2019-2022, project number 025/RID/2018/19, financing amount of PLN 12,000,000.

The purchase of instruments (UV/VIS Lambda 25 spectrometer, StarTECH System, Optima 8000 ICP-OES) was funded from the MOLAB program "Development of the research capacity of specialist laboratories of public universities in the Świętokrzyski Region" funded under the Innovative Economy Operational Programme.

\section{Conflict of Interest}

The authors declare no conflict of interest.

\section{References}

1. MAVAKALA B.K., LE FAUCHEUR S, MULAJI C.K., LAFFITE A., DEVARAJAN N., BIEY E.M., GIULIANI G., OTAMONGA J.P., KABATUSUILA P., MPIANA P.T., POTÉ J. Leachates draining from controlled municipal solid waste landfill: Detailed geochemical characterization and toxicity tests, Waste Manag. 55, 238, 2016, doi:10.1016/j.wasman.2016.04.028.

2. SMAOUI Y., MSEDDI S., AYADI N., SAYDI S., BOUZID J. Evaluation of influence of coagulation/flocculation and Fenton oxidation with iron on landfill leachate treatment, Envir. Prot. Eng. 45 (1), 139, 2019, doi: 10.5277/EPE190111.

3. JEGAN DURAI N., GOPALAKRISHNA G.V.T., PADMANABAN V.C., SELVARAJU N. Oxidative removal of stabilized landfill leachate by Fenton's process: process modeling, optimization and analysis of degraded products, RSC Adv. 10, 3916, 2020, doi: 10.1039/ C9RA09415F.

4. RAGHAB S.M., ABD EL MEGUID A. M., HEGAZI H. A. Treatment of leachate from municipal solid waste landfill, HBRC J. 9 (87), 2013, doi: 10.1016/j.hbcj.2013.05.007.

5. RUONAN G., QI M., HUIXUAN Z., BO L., QINGFENG C., XIUWEN C. Construction of $\mathrm{Fe}_{2} \mathrm{O}_{3} / \mathrm{Co}_{3} \mathrm{O}_{4}$ /exfoliated graphite composite and its high efficient treatment of landfill leachate by activation of potassium persulfate, Chem. Eng. J. 355, 952, 2019.

6. VILAR A., EIROA M., KENNES CH., VEIGA M. C. Optimization of the landfill leachate treatment by the Fenton process, Water and Environment Journal, 27 (1), 120, 2013, doi: 10.1111/j.1747-6593.2012.00333.x.

7. GAWDZIK J., MUSZYŃSKA J. SIKORSKI M. Effect of $\mathrm{H}_{2} \mathrm{O}_{2}$ sequential dosing in the Fenton process on leachate treatment, Desalin. Water Treat. 134, 310, 2018. 
8. GROSSER A., JELONEK P., NECZAJ E. Trends in landfill leachate treatment; interdisciplinary issues in engineering and environmental protection (ed.) WIŚNIEWSKI J., KUTYŁOWSKA M., TRUSZ-ZDYBEK A. Oficyna Wydawnicza Politechniki Wrocławskiej, 95, 2015, ISBN: 978-83-7493-890-7 [In Polish].

9. MENG-HUI Z., HUI D., LIANG Z., DE-XI W., DI M. A review on Fenton process for organic wastewater treatment based on optimization perspective, Sci. Total Environ. 670, 110, 2019.

10. ARJUNAN B., KARUPPAN M. A review on Fenton and improvements to the Fenton process for wastewater treatment, J. Environ. Chem. Eng. 2, 557, 2014.

11. SINGA P.K., ISA M.H., HO Y.-CH., LIM J.W. Mineralization of hazardous waste landfill leachate Rusing photo-Fenton process, E3S Web of Conferences, 65 (05012), 2018, ICCEE 2018, 1-8, doi: 10.1051/ e3sconf/20186505012.

12. FERROKHI M., DINDARLOO K., ALI JAMALI H. Optimization of Fenton oxidation process for biodegradability enhancement of a mature landfill leachate Rusing response surface methodology, Res. J. Environ. Toxicol. 9 (6), 274, 2015, doi: 10.3923/rjet.2015.274.289.

13. SKOCZKO I. Pesticide decomposition by the Fenton method using $\mathrm{MgO}_{2}$, Rocznik Ochrona Środowiska,. 15, 1460, 2013 [In Polish].

14. MIRANZADEH M.B., ZARJAM R., DEHGHANI R., HAGHIGHI M., BADI H.Z., MARZALEH M.A., TEHRANI A. M. Comparison of Fenton and Photo-Fenton processes for removal of linear alkile benzene sulfonate (Las) from aqueous solutions, Pol. J. Environ. Stud., 25 (4), 1639,2016

15. DĄBEK L., OZIMINA E., PICHETA-OLEŚ A. Applying the combined processes of sorption and oxidation to remove organic compounds from an aqueous environment using the example of p-chlorophenol, Ecol. Chem. Eng. A. 19 (3), 275, 2012 doi: 110.2428/ecea.2012.19(03)029.

16. HUI Z., HEUNG J.C., CHIN-PAO H. Optimization of Fenton process for the treatment of landfill leachate, Journal of Hazardous Materials B 125, 166, 2005.

17. SANTIN-GUSMAN M., MORENO-ANDRES J., CISNEROS-ABAD M., AGUILAR-RAMREZ S. Optimization for Fenton process In removal of COD for landfill leachate treatment, Int. J. Environ. Sci. Dev. 6 (12), 920, 2015, doi: 10.7763/IJESD.2015.V6.722 .

18. BU G., XIAN P., ZHAN L., FENG X., TANG H. Optimizing operating conditions for advanced treatment of landfill leachate Rusing the coagulation-Fenton oxidation metod, Pol. J. Environ. Stud., 25 (5), 1863, 2016, doi: 10.15244/pjoes/63067.

19. BARBUSIŃSKI K. Intensification of wastewater treatment and stabilization of excess sludge considering Fenton's reagent, Silesian University of Technology, Zeszyty Naukowe No 1603, Gliwice 2004 [In Polish].

20. ROUDI A.M. CHELLIAPAN S., MELINI WAN MOHTAR WAN H., KAMYAB H. Prediction and optimization of the Fenton process for the treatment of lanfill leachate Rusing and artificial neural Network, Water, 10 (595), 1, 2018, doi: 10.3390/w10050595.

21. DANTAS E.R.B., SILVA E.J., LOPES W.S., NASCIMENTO M.R., LEITE V.D., SOUSA J.T. Fenton treatment of sanitary landfill leachate: optimization of operational parameters, characterization of sludge and toxicology, Environ. Technol. 2, 1, 2019 doi: 10.1080/09593330.2019.1576773.

22. GOWDA S.T., YASHASWINI S. Optimization of Fenton process, Int. J. Adv. Sci. Eng. Technol. 6 (1), 46, 2018. 